\title{
2 Methods of influence, layers of impact, cycles of change: A framework for analysis
}

\author{
Leonardo Morlino and Amichai Magen
}

\section{Introduction}

How should we conceptualize and evaluate the extent and nature of international influence, if any, on democratic rule of law (DRoL) developments in domestic systems? Throughout history, most studies in democratization have been characterized by a puzzling lack of systematic thinking about these fundamental questions. From the inception of modern democratization studies in the 1960s until the end of the Cold War, scholars of democratic transitions and consolidation largely conceived the outcomes of domestic political processes as being driven by national forces and calculations, at both elite and mass levels, and were reluctant to venture beyond the demos in search of the causes of democratization. What was true of studies regarding the development of democracy reflected a broader malaise in which research into international impact on domestic change was largely neglected for many decades by historians, political scientists and lawyers. The dominant paradigm of political sociology from Marx to Barrington Moore, for one, has stressed the importance of internal social structure and culture in the shaping of politics and the state, sidelining the calls of such eminent scholars as John Robert Seeley, in the late nineteenth century, and Otto Hintze, in the 1960s, to remedy the neglect of international factors in the explanation of domestic political developments (Almond 1989, 239-41). Indeed, the intellectual progeny of the same tradition continues to wield considerable influence (and yield meaningful insights) by emphasizing the importance of inherited cultural, ideological, socioeconomic, and institutional legacies to defining post-transition outcomes of democracy, attitudes to liberal values, as well as national and ethnic identities (Ekiert and Hanson 2003).

Several additional factors have conspired until fairly recently to suppress both theoretical and empirical research into international influence on domestic democratic development. When preoccupation with the internationalnational linkages arose in the aftermath of the Second World War - notably in the work of American diplomatic historians, political scientists and international relations theorists such as Almond (1950), Dahl (1950) and Waltz (1967) - the prism adopted first was a 'bottom-up' one, in which it was the 
impact of national factors on international politics that was the nexus of inquiry, not the other way around (Haas 1964; Keohane 1984; Krasner 1976). Normative judgments further stifled inquiry in this field. The dependency movement of the 1970s and 1980s, for instance, while drawing attention to the importance of external conditions on internal economic and political developments, perceived the influence of international factors to be wholly debilitating, rather than enabling (Wallerstein 1979; Cardoso and Faletto 1979). Developing countries, so the Marxist inspired theory proclaimed, were condemned to wallow in backwardness or suffer developmental retardation, by virtue of an international class system dominated by western capitalist institutions. The narrative of exploitation and damage infliction, on the part of the international system, discouraged open-minded analysis of the possible role of external actors in supporting or promoting democratic change in developing countries.

From the opposite side of the domestic/international divide, theories of international relations and international law have traditionally focused on horizontal outcomes at the supranational level (notably interstate balance of power, conflict, and cooperation), rather than the more vertical, "outside-in" linkages between international agents and domestic factors (Pevehouse 2002, 516). Even more so than their international relations peers, international lawyers have historically, and mostly remain, chiefly occupied with categorizing, analyzing and debating the rules of state responsibility, interstate relations and international organizations, largely shunning questions of domestic regime characteristics and the potential influence of international rules on national and sub-nation level systems (Fox and Roth 2000).

Although this lack of analytic attention has begun to be rectified, with increasing intensity and sophistication in the last two decades, important gaps in theoretical and empirical knowledge persist. Building on Charles Tilly's studies on the role of international competition in modern state formation (Tilly 1975), Peter Gourevitch's insights on the circularity of national-international interaction (Gourevitch 1978), as well as Robert Putnam's two-level international bargaining games (Putnam 1988), scholars working from within different theoretical traditions (neoliberal internationalism, sociological and historical institutionalism, and social constructivism) have, particularly since the end of the Cold War, contributed important insights on the impact of international conditions, organizations and networks, domestic security, economic, political, institutional, regulatory, legal and normative behavior (Busch and Milner 1994; Checkel 2002, 2005; Finnemore 1996; Goldstein 1998; Greif 2006; Ikenberry and Kupchan 1990; Kahler 1992; Keohane and Martin 1995; Pevehouse 2002; 2005; Pridham 1994; Risse, Ropp and Sikkink 1999; Russett and Oneal 2001; Whitehead 1996a). One body of literature focused on democracy in particular has began to theorize the mechanisms and pathways by which international factors may facilitate democratization in transitional states, invoking notions such as diffusion, contagion, gravity, demonstration effect, complex interdependence, convergence, emulation, socialization, learning, conditionality and even zeitgeist 
(Gleditsch and Ward 2006; Grugel 1999; Huntington 1991; Kopstein and Reilly 2000; Kubicek 2003; Linz and Stepan 1996; Pridham 1991; Simmons, Dobbin and Garrett 2006). These notions are of variable analytic usefulness. While Pevehouse's work on the linkages between membership of international organizations and transitions to democracy identifies important potential causal mechanisms of International Organization influence on regime change (Pevehouse 2002 and 2005), discussions of democratic diffusion (Gleditsch and Ward 2006; Kopstein and Reilly 2000; Simmons, Dobbin and Garrett 2006) fail to address causality or operationalize methods of external influence on domestic change (Kubicek 2003, 4).

\section{EU Cycles and Layers of International Democratic Anchoring (EUCLIDA)}

This chapter outlines an analytical framework designed to approach these questions; a framework which is subsequently put to the test with reference to each case study country, and which therefore provides the remainder of the volume with a cohesive structure for comparative analysis. In approaching this topic, we are consciously avoiding theory testing per se. Rather, since we are seeking to conceptualize and explain phenomena involving complex linkages between power, interests, norms, human agency and legal-institutional change, we engage in "analytical eclecticism" (Katzenstein and Okawara 2002), drawing selectively on the different theoretical traditions and insights we view as necessary to advance clearer, finer-grained and more reliable knowledge regarding the external-internal dynamic of democratization processes and, more instrumentally, enabling environments for successful DRoL developments in domestic systems. More precisely, the 'analytical ecleticism' we engage is, first of all, problem-driven and aimed at finding a framework to analyze in an empirically effective way several cases within a similar system comparative design. Thus, the traditional agency dominant literature on democratization (Morlino 1998; Whitehead 2001c) is complemented by the rationalist approach and the constructivist one in the way Fearon and Wendt $(2005,68)$ suggest: "the most fruitful framing of 'rationalism v. constructivism' is a pragmatic one, treating them as analytical lenses for looking at social reality", as do Checkel (2005, 801-26) as well as Risse and Ropp (1999, 272-3) when adding strategic calculations or instrumental reasoning to role playing or persuasion and to normative suasion or institutionalization and habitualization.

The overarching notion we propose as a means of conceptualizing external influence on domestic DRoL change processes, and the interaction between the two is democratic anchoring. At the highest level of analysis, anchoring affirms an essentially dichotomous, two-level prism according to which in the contemporary international system nation-state regimes are subject to variably dense external (international, transnational and supranational) linkages, pressures and stimuli influencing internal conditions of democracy, yet democracy 
and processes of democratization exist solely within national systems, so that the proper level of analysis of democratization processes remains essentially domestic and the correct nexus of inquiry ought therefore to focus on identifying empirically discernable external-internal agency interaction.

Any analysis of international influence on domestic democratic change, in other words, must begin with the recognition of an overarching, structural constraint regarding the role of external factors. Since, by definition, democratization involves processes of change in the governing of a demos - a selfdefined community based on citizenship and distinguishing the 'us' from the 'them' - such processes always $\overline{\bar{\equiv}}$ h a fundamental sense, an essentially "domestic drama" (Whitehead 1986). Even in the most extreme cases of external intervention therefore (such as long-term control by an occupying power), democratization in any meaningful sense must entail the free exercise of rights of citizenship in a sovereign entity, all of which depend on domestic actors, institutions and procedures. As such, it is difficult to view international factors as truly independent variables, since democratization processes (unlike modernization, for instance) are ultimately always carried through domestic actors, institutions and procedures. It is external-internal interactions, rather than external factors per se, which are more accurately said to shape domestic outcomes. The effects of international factors are, thus, only apparent in changes occurring within national and sub-national systems where the concept of a demos has any real meaning.

This does not mean that the notion of democratic anchoring falls into the trap of "methodological nationalism" (WXimmer and Glick Schiller 2002). Although democratization processes $\overline{\bar{\nu}}$ how unfolding within a radically transformed international environment compared to two decades ago (thus challenging our existing models), this does not mean, as Grugel (1999) suggests, that it is no longer legitimate to maintain a basic analytical distinction between domestic and external levels of analysis in democratization studies. A more accurate conception, we submit, is to embrace the nation/state/ society as the proper sociopolitical context of inquiry into democratization processes - recognizing the inescapability of the primacy of the domestic in democratization processes - and begin to address the various parts of the externalinfluence-on-domestic-change puzzle in an integrated manner. This involves three primary, interrelated components: firstly, identifying the different methods of possible external influence and different modes by which these interact with domestic factors; secondly, conceptualizing the extent and nature - or what we call 'layers' - of external impact, and; thirdly, tracing temporal and spatial sequencing - or what we call 'cycles' - of such an impact.

\section{Methods of influence, modes of interaction}

We identify four main categories of methods of influence - control, conditionality, socialization, and example - each involving different modes of interaction with domestic systems and drawing on different theoretical traditions. ${ }^{1}$ 


\section{Democratic control}

At the hardest edge of the spectrum of intervention tools available to the most powerful western state actors (US), regional organizations (NATO, EU) or global fora (UN), is the use of military force directly to overthrow an authoritarian regime and attempt to install a viable democratic regime in its place or, more commonly, attempt to build basic conditions of public security and legality as part of a post-conflict state reconstruction effort. ${ }^{2}$

In instances where elected governments have been forcefully removed by military coup and have requested the intervention of external actors to restore conditions of public order and democracy - as in Haiti (1994) and Sierra Leone (1998) - virtually the entire international community has accepted the use of coercive power as a legitimate means to reinstate the ousted democratic regime (Stromseth Wippman and Brooks 2006). Where military intervention took place without domestic invitation, the legality of invasion pacts has been disputed, notably in cases of unilateral action (such as the US invasion of Panama in 1989 and Iraq in 2003) or where no UN Security Council authorization was obtained by external actors prior to the initiation of military action (such as the above or NATO's action against Serbia in 1999). ${ }^{3}$

Nevertheless, since the end of the Cold War, the erosion of non-intervention principles, coupled with a strengthening of human rights and humanitarian intervention norms, have resulted in a proliferation of instances of "imposed democratization" (see Whitehead 2004, 137). These have involved a range of "neo-trusteeship" arrangements (Fearon and Laitin 2004), extending from full military occupation led by a handful of states (Iraq) or a broader coalition (Afghanistan), to variably robust UN peacekeeping and peace-building missions (Liberia, East Timor) and long-term transitional administrations (such as Bosnia-Herzegovipand Kosovo) - all with substantial post-conflict state-building and rule-o promotion dimensions (Chesterman 2001; 2004b; Hysa 2004; Peceny 1999). Indeed, a focus on the establishment of conditions of personal security and a popular perception that leaders respect and are subject to the law, is increasingly identified as being perhaps the single most important factor in determining the success or failure of democratic state building (Bratton and Chang 2006).

What unites the various forms of these interventions is a common method of influence, namely control - or what Ikenberry and Kupchan have called “internal reconstruction" (Ikenberry and Kupchan 1990, 58). Transformation of domestic institutions and laws is achieved through direct intervention in which the international/domestic membrane is pierced, often in the aftermath of war. Though highly costly, often controversial, and of mixed success, taking control of a country's political institutions and processes, has historically been one method by which international actors can facilitate democratization, or hamper it, as in the case of Soviet policy towards Central and Eastern Europe during the Cold War. Owen (2002) lists no fewer than 198 cases 
(between 1555 and 2000) of forc $\overline{\bar{\nu}}_{\text {fforts by individual or groups of states }}$ to create, preserve or alter the political institutions - including constitutions and laws - within a third state, with post-World War II instances of such imposition dominated by western great powers efforts to promote liberal democracy. As a method of influence, control can be 'heavy' or 'light' - the latter involving efforts to avoid local dependency through the early and/or gradual transfer of control functions to indigenous authorities. It may extend over the entire territory of a state, or be limited to seizure of strategic posts, notably the capital city and the state's borders. It may exist for a relatively short period of time, as in the case of the Allied occupation of Japan and Germany, or involve open-ended, long-term control by a succession of controlling agents, as in the case of Bosnia-Herzegovina. ${ }^{4}$

\section{Democratic conditionality}

Short of deploying coercive intervention, powerful external actors manipulate threats of punitive measures and promises of positive rewards to alter the costs and benefits of domestic decision policy choices. Exogenously generated sticks and carrots act either directly, by altering the instrumentalist calculations of governing elites, or indirectly, through the relative weakening of veto players and the differentiated empowerment of domestic change agents (Tsebelis 2002; Schimmelfennig and Sedelmeier 2005a).

Methods of democratic conditionality fall into two broad categories: negative and positive. The first refers to non-military, coercive political, diplomatic and economic measures used to induce policy change in a targeted country (Hart 2000; Hufbauer, Schott and Elliott 1990; A. Smith 1995). Although the efficacy and preferred design of sanctions are hotly debated, serious violators of democratic principles are now far more likely to suffer punitive measures than was the case even 20 years ago. ${ }^{5}$ Indeed, since the end of the Cold War, it is difficult to find cases where political, diplomatic or economic sanctions of some sort were $\overline{\overline{\bar{\nu}}}$ mposed in reaction to a breakdown in democracy, as is evident from the imposition of sanctions on: Belarus (in 1997 and 2005), Cambodia (1997), Fiji (2000 and 2007), Guatemala (1993), Haiti (1991 and 1994), Niger (1999), Pakistan (1999), Paraguay (1996), Peru (1992), Thailand (2006), Venezuela (2002) and Zimbabwe (2002). Worldwide, as Marinov $(2004,7)$ shows: "an illiberal state ran about $21 \%$ risk of being subject to foreign pressure over its lack of political pluralism in the year 2000. This compares to only about $3 \%$ in $1983 " .6$

Still more marked has been the increased deployment of positive conditionality in the democracy promotion policies of leading western states and the international organizations they dominate in the post-Cold War period (Dimitrova and Pridham 2004; Kelley 2004b; Woods 2005). ${ }^{7}$ Since the collapse of Soviet communism in particular, western international actors have generated a wide range of policy instruments to link progress in democratization to the receipt of various international entitlements. These have 


\section{Leonardo Morlino and Amichai Magen}

included making collective recognition of new states and governments dependent on their adherence to democratic practices (Murphy 1999), bundling the conferment of security, trade and aid benefits with acceptance of democracy and human rights clauses in contractual agreements, and sanctioning existing member states for conduct deviating from collective norms (Halperin and Lomasney 1998; Horng 2003; Piccone 2004).

Moreover, democratic conditionality assumes two broad forms: the first, and historically by far the more common of the two, has been ex ante conditionality. Here benefits are provided prior to confirmation of compliance or as a simple matter of reinforcement. Despite a recent, gradual shift away from it, ex ante conditionality still characterizes the bulk of aid expenditure policies practiced by multilateral development banks and leading donor states (Mosley.Hudson and Verschoor 2004; Svensson 2000). The democracy and rule-of $\overline{\overline{\bar{\nu}}}$ promotion policies of some regional organizations, such as the Organization for Security and Cooperation in Europe (OSCE), and human rights and democracy clauses inserted by the EU into its regular free trade agreements with third countries, similarly follow the ex ante model (Horng 2003). Overall, studies in the last two decades have shown a meager, though not entirely negligible, systematic relationship between this variety of positive conditionality and policy changes in targeted states. However, as Collier argues, failures of conditionality may be at least partially attributable to perverse incentives within and among donor institutions, resulting in donors being insufficiently motivated to punish recipients of aid for non-compliance (Collier 1997; Collier and Dollar 2004).

The second form of democratic conditionality involves "reinforcement by reward", in which material and symbolic goods are provided only ex post in cases where the targeted government complies with the conditions, and the benefit is withheld where it does not. ${ }^{8}$ Governments that fail to respond to incentives to adopt and implement prescribed reforms are neither coerced nor rewarded, but are left to bear the costs of exclusion (from aid allocation, favorable trade and investment conditions, security guarantees, membership in organizations or other forms of linkages to benefit-granting international regimes) until such a time as they, or a successive government, decide to comply. Until recently, the number of international actors able and willing to deploy this type of external pressure has been very small. In Europe, where the practice of ex post conditionality has assumed the most advanced, institutionalized forms, there have been glaring cases of "wasted leverage" (K. Smith 2001, 43). Most notably, the Council of Europe has largely opted to forego stringent membership conditionality in favor of a policy emphasizing postaccession socialization into western liberal practices. Its pre-accession procedures, therefore, have been slack, a reality epitomized by the controversial acceptance of Albania (1995), Russia and Croatia (1996), the southern Caucasus countries (1999 to 2002) and Bosnia-Herzegovina (2003). Indeed, even in Europe, as Schimmelfennig (2005, 832-3) argues $\overline{\bar{\lambda}}$ "reinforcement by tangible punishments and rewards has been limited to the two organizations 
capable of providing material incentives and disincentives in the areas of security and welfare: the EU and NATO." Outside Europe, the World Bank's growing disappointment with the results of its traditional ex ante conditionality policies, has spurred it, over the last several years, to shift to a concept of what it calls "selectivity" - where aid agreements are only concluded with those states whose policy choices already demonstrate a prior commitment to reform (World Bank 2001, 193-6). This shift does not reflect any truly new insights into external influence methodology since "to an extent selectivity is no more than ex-post conditionality." (Mosley, Hudson and Verschoor 2004, 220). In essence, the same logic underlies the Millennium Challenge Corporation (MCC) initiative, launched by the Bush administration in March 2002. The MCC preconditions the receipt of aid by targeted governments on a demonstrated "commitment to policies that promote political and economic freedom, investments in education and health, control of corruption, and respect for civil liberties and the rule of law by performing well on 16 different policy indicators." 9

Unlike coercive interventions that rely on a method of control, the mechanisms of influence underlining punitive and positive external incentives assume (a) that domestic actors retain a degree of autonomous choice and (b) that those actors respond to a "logic of anticipated consequences and prior preferences:" (March and Olsen 1998, 949). All strategies of conditionality, in other words, follow an actor-based, rational bargaining logic of influence, emphasizing a utilitarian calculation where domestic decision constituencies are affected by the costs and benefits of compliance. In this latter sense, conditionality is linked to example since domestic costs will be higher where there is a weaker cultural match between the externally driven rule and domestic norms. The potency of conditionality varies and can be shaped along several axes, including: the relative bargaining power of the actors (including the availability of realistic alternatives for the targeted state); size and speed of rewards; the credibility of conditionality; the size and distribution of domestic costs of compliance; and the determinacy of conditions applied. ${ }^{10}$ Determinacy (or specificity) also plays an important role in shaping the effectiveness of conditionality (Schimmelfennig and Sedelmeier 2005a). Determinacy refers to (a) the clarity and (b) the formality of the rule - what some have called the "density of norms" (Jacoby and Cernoch 2002, 320). The more specific and formal the rule, the higher its determinacy value. High determinacy serves an informational role, acting as a road map for the targeted government, and at the same time enhances the credibility of the conditionality, as it narrows the scope for interpretation and therefore manipulation of the rule and aids monitoring of compliance. Moreover, conditionality allows other methods of influence, such as the exercise of normative pressure and persuasion, to be pressed by the promoter with greater confidence, since these rhetorical actions are then made in the shadow of material incentives for compliance (Kelley 2004a). Conditionality can influence the target government either directly, through bargaining, or indirectly through 


\section{Leonardo Morlino and Amichai Magen}

the differential empowerment of domestic actors. In the latter sense, conditionality changes the domestic power dynamics in favor of domestic actors with incentives to adopt EU rules and norms, and strengthening their position in relation to opponents in government and society.

\section{Democratic socialization}

If incentive-based instruments rely on the superior leverage external actors can wield, what may be termed "international democratic socialization" represents a distinct method of external influence which aims to facilitate internalization of democratic norms, policies and institutions through the establishment and intensification of linkages between liberal international fora and state actors in transitional countries (Checkel 2001; 2005; Johnston 2001; Kelley 2004a; Levitsky and Way 2005; Schimmelfennig 2005a; Schimmelfennig and Sedelmeier 2005a).

International democratic socialization - defined as a process of inducting individuals and states into the democratic norms and rules of a given regional, international or transnational community - involves variably intrusive linkages, with the socialization potential and practices of different international actors ranging on a continuum of intensity. As Levitsky and Way assert, at the highest level of abstraction there exist at least five dimensions of such linkages: (1) economic ties, which include trade, credit, investment and assistance; (2) geopolitical ties, which include membership in, or other forms of association with, regional or global governance institutions and alliances; (3) social linkage, including migration, diaspora communities, technical and professional epistemic communities and elite education; (4) communication linkage, including cross-border telecommunications and media; and (5) transnational civil society ties, including involvement with international NGOs, multilateral corporations, social entrepreneurship organizations, party foundations, bar associations, and churches (Levitsky and Way 2005).

Focusing on a narrower, though still vast category of international factors, Slaughter (2004) has flagged the importance of "government networks" (information networks, enforcement networks and harmonization networks, operating across regulatory, legislative and judicial functions of governance) to western efforts to transform bad governments, or partially replace them in failed, weak or transitional states. Horizontal regulatory networks of national officials interacting in their respective issue areas range from anti-money laundering and anti-corruption regulation, to law enforcement, and human rights protection. Information networks involve judges, legislators, regulators and enforcement agents coming together in a myriad of fora, such as the Organisation for Economic Co-operation and Development (OECD) and the Commonwealth, to discuss, collect and distill professional best practices; while horizontal enforcement networks (such as INTERPOL and EUROPOL, at the global and regional levels) are increasingly compelled to interact due to the growing activity in transnational illegal activities (Slaughter 2004, 135-44). 
Many of the horizontal networks, as well as some of the modes of linkage identified above (social, educational, technological, and cultural), represent diffuse, non-institutionalized mechanisms of potential influence. These may be understood as situated closer to the soft end of the intervention spectrum, adjacent to the dispersed modern world society scripts identified by Meyer and others as having been influential in the spread of a host of "administrative rationality" features in transitional countries. ${ }^{11}$

International actors also deploy a range of tools intended to "name and shame' states into compliance with democratic practices, with little or no institutionalized engagement and attempts at deliberative induction into community practices and norms. Normative pressure can take the form of informal verbal pressure where a prominent leader of a democratic country, international institution or NGO makes use of the bully pulpit to laud certain practices, berate others, or place a targeted phone call to a foreign leader at decision-making junctures, with specific demands. ${ }^{12}$ Normative pressure can, and increasingly does, assume more formal, structured shape. Observation of national elections, plebiscites and referenda to monitor procedural fairness, violations of basic political and human rights tied to electoral contestation, and even campaign financing in countries claiming to be democratic, has become the international norm, and has reached a high degree of institutionalization (Carothers 1997; Santa Cruz 2005). Governments, international organizations and leading NGOs - such as Amnesty International, Transparency International and Human Rights Watch - issue regular declarations, reports and demarches, openly criticizing countries on a host of ruleof-law issues, from corruption, to abuse of rights, to detention and prison conditions. The Bureau of Democracy, Human Rights, and Labor of the US Department of State, for example, is mandated under the Foreign Assistance Act (FAA) to submit to Congress annual country reports on human rights practices and democratic government. The first reports, compiled in 1977 , covered 82 countries sreceiving US aid, whereas in 2006, 196 reports were presented to Congress. Among the 46 members of the Council of Europe, similarly, a number of intergovernmental committees monitor and report on the state of compliance with Council of Eyrope conventions and non-binding guidelines on a broad range of rule-of $\overline{\bar{v}}_{\text {issues. }}{ }^{13}$

The post-Cold War explosion of interest in the quality of domestic governance has, in the last decade, generated an unprecedented proliferation in the compilation and dissemination of democracy and governance indicators. ${ }^{14}$ Based on the maxim that you can only monitor what you measure, a plethora of international actors - from private investors and corporate risk analysts, to multilateral development agencies and academics - now generate dozens of governance indicators and databases, that provide ready, quantitative canon fodder for business, policy and academic audiences to critique practically everv country in the world on a broad range of democracy, human rights and rule-

At the harder, more heavily institutionalized edge of the linkage category, furthermore, we locate what Slaughter calls "vertical networks" - global or, 
more commonly, regional organizations and their deliberative processes, which perform two related functions of international socialization. First, international institutions, such as the United Nations Development Program (UNDP), United Nations Education, Scientific and Cultural Organization (UNESCO), the World Bank, International Labour Organization (ILO) and OECD, function as norm entrepreneurs and teachers of norms - generating and disseminating information about appropriate templates of policy, institutional design and administrative conduct (Finnemore 1996; Finnemore and Sikkink 1998; Keck and Sikkink 1999). Second, international organizations and the processes they foster act as social environments that shape domestic policy choices, behavior and possibly even the identity of governmental, bureaucratic and broader societal actors who interact with them (Grigorescu (-2003); Johnston 2001; Simmons, Dobbins and Garrett 2006).

Liberal international actors can, and do, shape the fora they control in an effort to reconfigure the preferences and identities of targeted states. Since the end of the Cold War, regional organizations in particular have defined the international democratic socialization of transitional states as a new core task for themselves (first, in post-Communist countries and Latin America, extending gradually into Africa), and devised an increasingly ipcritutionalized set of instruments to support and promote, inter alia, rule-or $\equiv_{\text {reforms }}$ by fully or partially anchoring targeted countries in pre-existing international liberal communities. ${ }^{16}$ Beyond Europe, international democratic socialization mechanisms have so far been less robust, but present nonetheless. In 1990, for example, the Organization of American States (OAS) - in which all 35 independent states of the Americas are members - established a Unit for the Promotion of Democracy, to encourage members "to renew, preserve and strengthen democratic institutions." 17 The Inter-American Juridical Committee of the OAS, similarly, polices the implementation of the InterAmerican Democratic Charter (adopted on 11 September, 2001), and provides an institutionalized platform for regular deliberation and the promotion of legal integration in a range of rule-o istration of justice, measures to combat crime, drug trafficking, terrorism and corruption, police standards, judicial cooperation, access to justice, and protection of fundamental rights. ${ }^{18}$

There is some evidence, too, that the use of international socialization mechanisms is proliferating geographically and thematically. It remains to be seen, for instance, whether the African Peer Review Mechanism - established under the auspices of the African Union (AU) in 2002 as part of growing international donor pressure for better governance - would or would not evolve into a useful collective peer pressure mechanism capable of inducting states into the AU's formal commitment to "promote and protect human and people's rights, consolidate democratic institutions and culture, and ... ensure good governance and the rule of law." 19 In an attempt to ensure that emerging powers buy into the core tenets of the US-led international order, moreover, Washington has been in the last several years striving to include countries like 
China, India and Brazil in a diverse set of regional and global fora ranging from G-7 meetings and the Inter-American Development Bank, to the International Monetary Fund (IMF), the World Health Organization (WHO) and the World Trade Organization ${ }_{\Lambda} \mathrm{WTO}_{\Lambda}$ (Drezner 2007).

Whereas external incentives modes of influence follow rational choice expectations of state behavior, theoretically mechanisms of state/agent socialization sit more comfortably with norm-based, social constructivist and social psychology explanations for individual and collective action. The notion of international democratic socialization, in other words, assumes that domestic decision-makers are themselves cognitive-social actors that respond, at least in part, to a "logic of appropriateness", where ideas, norms and identity shape compliance with and internalization of rules and institutions (March and Olsen 1998, 951). According to this method of influence, external impact on domestic democratic development is not reducible to materialist, cost-benefit balancing of predetermined interests. Rather, those interests themselves are best understood as the product of social structures and interactions. Since "actors who enter into a social interaction rarely emerge the same" (Johnston 2001, 488), processes of rule- $\overline{\bar{\equiv}}$ v change occur through deliberative, communicative processes of habituation, argumentation and persuasion (Checkel 2005; Risse 1999).

Socialization may take more than one form. Agents may change their domestic institutions and policies by virtue of having their choice of modes of behavior bounded by external organizations, networks and rules (Jacoby 2004; Jones 1999) - complying with rules and norms expected of them by virtue of their belonging to a certain community, irrespective of whether they internalize these rules and accept them as their own. Alternatively, following a logic of appropriateness may extend beyond ordering from a circumscribed menu of socially acceptable policy choices, and involve agents internalizing community or organizational norms as appropriate, legitimate and correct in their own right. ${ }^{20}$

Moreover, the 'influence density' of different international socialization mechanisms (whether horizontal or vertical) would differ depending on a variety of factors, including the duration and intensity of interaction, the perceived legitimacy of the socializing actor, the determinacy of the rules it seeks to have internalized, and the financial and technical resources it can muster to encourage socialization. Thus, unlike the more passive democratic example method of influence, democratic socialization involves an active, deliberative aspect where impact on domestic systems is assumed to be enhanced by the intensification of opportunities for complex learning, deliberation and shifts in identity. In institutional terms this can happen through the development of political dialogue, bureaucratic and professional collaboration and academic networks, as well as mass exchanges through popular media, movement of persons, youth, education and cultural exchanges. Socialization will be eased where externally driven reforms are seen as legitimate and the demand for compliance deemed by domestic constituencies to be substantively and procedurally fair. 


\section{Democratic example}

Finally, the fourth method of external influence on domestic ruleopment is captured in the notion of democratic example, or demonstration. According to this model, state and societal actors in transitional states accept new rules, institutions and policy choices not as a result of external incentives or socialization, but through sheer emulation of a successful external model. The prosperity, security, freedom and eunomia of leading democratic states serve as exemplars, a "city upon the hill" which others are inspired by and seek to mimic (Haveman 1993).

A number of causal processes have been suggested for emulation of a successful democratic example. Voluntary lesson drawing (Dolowitz and Marsh 2000; Rose 1991; Schimmelfennig and Sedelmeier 2005a) - which can assume straightforward copying or loose imitation - can take place as the result of internal dissatisfaction with the policy status quo, coupled with the transferability of external norms, policies and institutions. This assumes certain capacities and a sequence of policy decisions: domestic policy-makers are dissatisfied with the existing state of affairs; they define the problem and mark it as potentially solvable, or at least improvable, through the adoption of new rules, institutions or policies; they look outside their domestic system to an external source identified as a potential model for emulation; form the perception that the external practices, rules or institutions are successful in solving difficulties identical, or at least comparable to those at home; determine that the external rules are not only technically transferable, but politically acceptable (Schimmelfennig and Sedelmeier 2005a, 22-4). A second main approach to emulation relies on insights from group theory in social psychology. Free of control, conditionality or active induction, some scholars suggest that geographic (Kopstein and Reilly 2000; Whitehead 2001c) and psychological proximity (Rose 1993) facilitates emulation, a phenomenon which helps explain the temporal and regional sequencing of democratization processes (Lankina and Getachew 2006). From this perspective, actors emulate the conduct of their self-identified peer group, with which they identify and strive to be associated. World society scholarship and literatures on epistemic communities offer additional strands on the causal processes of emulation. Meyer and others suggest that countries establish institutions and sign up to various international obligations for diffuse, "world social" reasons, acquiring a sense of belonging and identification with modernity by rhetorically and legally embracing human rights, labour, environmental and public health standards, even where they lack both the capacity and intention to put them into effect (Meyer et al. 1997a; Hathaway 2002). These processes of emulation may be catalyzed by the presence of epistemic communities, where professional, technocratic and academic groups influence governments to adopt new rules and policies by setting agendas, defining problems and formulating policy solution options in a manner that makes them accessible to domestic decision-makers (Simmons, Dobbin and Garrett 2006, 800). 
Democratic anchoring, in sum, may involve four main methods of influence, ranging on a spectrum of measures, from deliberate, highly institutionalized, intrusive (occasionally coercive) mechanisms, to the type of diffuse scripts identified by world society scholars. In practical, policy-oriented terms, the most promising and potentially malleable methods of anchoring are represented by the two mid-range methods of influence: conditionality ${ }^{21}$ and socialization, since anchoring through control usually involves highly costly (sometimes in blood as well as money) instruments of engagement that western actors are generally reluctant to expend, whereas democratic examples entail culture, ideas and norms the construction and controlled use of which policy actors are generally ill prepared for. Moreover, in a strictly empirical perspective, while control is very easy to be proved because its same characteristics, emulation is very elusive and in the best case can be indirectly suggested. At the end, however, as Chapter 3 demonstrates, it is largely through the gradual development and deployment of the conditionality and socialization type methods of democratic anchoring that the EU has sought to transform neighboring countries. All in all, these are the reasons why we decided to focus on those two mechanisms and leave out control and democratic example or emulation.

\section{Layers of impact, cycles of change}

If we now have a clearer understanding of the types of external methods of influence that exist and their different logics of persuasion, the next step is to develop an integrated framework for an empirical analysis of external actor impact on domestic change processes, which involves asking what that impact actually consists of, how it occurs, and in what sequences.

Academic engagement with these questions, where it exists at all, has tended to remain rather evasive. Lawyers approaching the topic of external influence on domestic legal reforms have sought to avoid the methodological challenges of looking beyond formal compliance with international rules, into genuine implementation of commitments (Hathaway 2002). The problem of implementation and internalization is also central in the 'spiral model', proposed by Risse and Sikkink (1999, esp. 17-35) and in the 'membership conditionality' model developed by Schimmelfennig (2005a), who set as their dependent variable formal and informal "rule adoption" involving the transposition of EU law into domestic law, the restructuring of domestic institutions according to EU standards, and the change of domestic political practices according to EU practices (Schimmelfennig and Sedelmeier 2005a, 7).

Here we propose that democratic anchoring involving external actor efforts to promote legal, institutional and behavioral change should be conceptualized as potentially involving three related, but analytically distinct "layers" of impact, namely, rule adoption, rule implementation, and rule internalization. 


\section{Rule adoption (RA)}

Following Schimmelfennig and Sedelmeier's formulation (2005a), RA involves the transposition of EU mandated rules and standards into domestic laws, the restructuring of domestic institutions according to EU rules and the changing of domestic political practices in line with EU standards. With regard to the DRoL, rule adoption concerns five main substantive domains. The first two, that is, (1) protection of civil freedoms and political rights and (2) institutional and administrative capacity to formulate, implement and enforce, refer to the moment when the decision to have a democracy is made and implemented. In fact, they substantiate that decision. The other three domains to include in the analysis are: (3) the independence of the judiciary and a modern justice system; (4) the fight against corruption, illegality and abuse of power by state agencies; and (5) effective "civilian control of the police and other security forces.

Within those domains RA means the formal passage of domestic legislation, the establishment of domestic institutions, as promoted by the relevant external actors. The scope and intensity of RA may vary extensively. Adoption may be limited to harmonization of legislation in specific, functional, 'low-politics' areas. At the other end of the spectrum, insertion can involve fundamental constitutional provisions that go to the heart of national sovereignty, and may involve massive en bloc acceptance of external laws. RA may also entail a commitment to ongoing, even future, adjustment of domestic rules - as is the case in the European Economic Area (EEA) countries with regard to Single Market rules.

\section{Rule implementation (RIm)}

Here, we are considering preliminarily the development or improvement of the rules, governing institutions, administrative structures that are necessary to implement the required and possibly adopted changes. That is, to have any implementation process there has to be prior development of institutional and administrative capacity (IAC). In our view this is one of the key factors

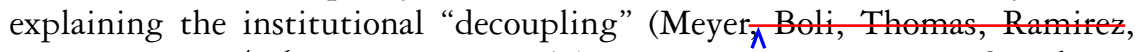
1997a, esp. 154-6) or "institutional hypocrisy" (Katzenstein and Iankova2003) those and other authors suggested. That is, the gap between formal rule adoption and implementation. Our hypothesis here is that if we have poorly developed institutions and bureaucracy that decoupling becomes very obvious. Furthermore, we should be ready to observe deliberate emptying of reform content by governmental actors who feel compelled (by domestic or external pressures) to assume formal legal or institutional commitments, but who then act to minimize, retard or completely block the intended effects of those commitments.

The difference, here suggested, between institutions and administration is a classical one where the key institutions, such as cabinet, parliament and 
magistracy are differentiated from bureaucracies, local and central. The necessity of such a development has already been a crucial point of debate in western European countries when a reformist government comes to office and tries to implement the changes that made possible its victory in political elections. Likewise, there can be the strongest elite commitment to rule adoption and rules can be approved, but if there is little or no IAC, then any decision is bound to remain just on paper.

RIm goes in the same five directions as RA: (1) protection of civil freedoms and political rights; (2) additional institutional and administrative structures to formulate, implement and enforce the law; (3) judicial independence and a modern justice system; (4) fight against corruption, illegality and abuse of power by state agencies; (5) police reform and civilian control of the security forces.

\section{Rule internalization (RI)}

RI means the acceptance of transferred rules, beyond formal adoption among state bureaucracy, political elites, relevant groups and the wider public, that is, a slower and gradual sub-process of legitimation of both the adopted rules and the institutions that were set in motion, making the RA and the development of IAC more than a superficial result without actual meaning. We can assume that only when RI gradually takes place does the implementation, which is relevant for the growth of DRoL, actually take place as well.

The entire framework with its three layers may be better presented by answering three related questions: how rule adoption is achieved; how the implementation is carried out; and how some degree of rule internalization is achieved. The reply to these questions also allows us to present our main hypotheses, but before moving on in this direction the basic lines of our reasoning can be clarified by making explicit the underlying matrix (see Table 2.1). The matrix also helps to stress and clarify an important theoretical feature. The dimension we call 'institutional, administrative structures' refers to the development of institutional and bureaucratic capacity and entails the three processes of RA, RIm and RI. But here, actually, two different moments in time are conflated for analytical reasons, although the time difference has to be maintained for a correct reading of the process. In fact, only when that capacity begins developing in at least the first and second processes (RA and RIm) (see the third column in Table 2.1, i.e. the vertical direction of the matrix), can the real process of RI actually begin; this is relevant for the development of that entire process (see the third row in Table 2.1, i.e. the horizontal direction of the matrix).

Before going on to propose conditions and pathways under which the three layers of change occur, it may be useful to add the dimension of temporality and sequencing to the equation. It is proposed that democratic anchoring involves 'cycles', as well as layers of change. Indeed, as also proposed in the "spiral model" by Risse and Sikkink with the "boomerang throws" (1999a, 18), anchoring is a long iterated process, where the different events and moments, 


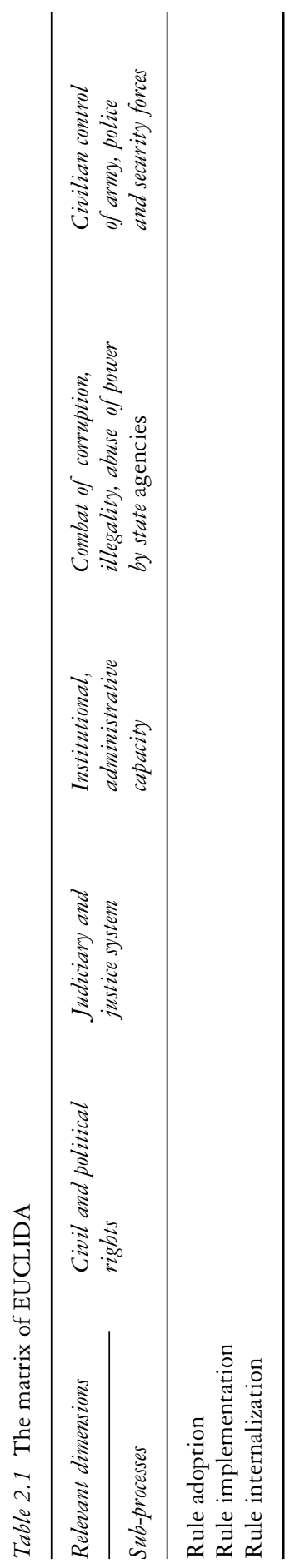




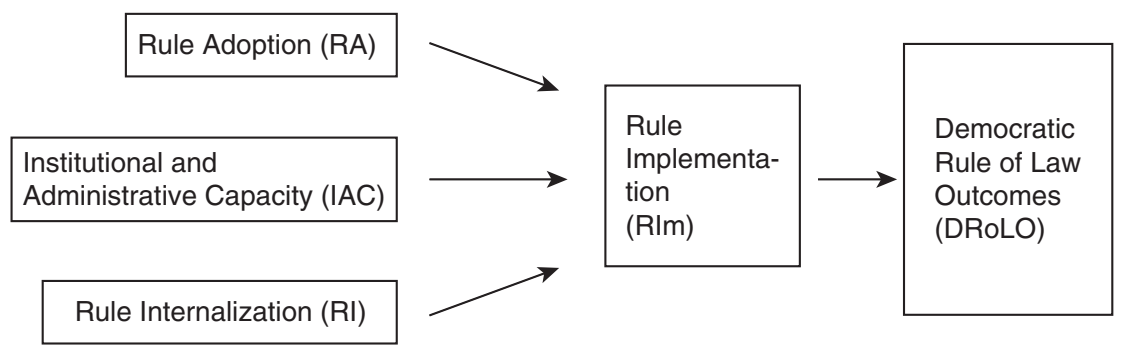

Figure 2.1 The outcomes of EUCLIDA

occasionally close in time, in one sector follow the same direction. Prolonged stops, delayed effects and reverse of direction may be anticipated before the DRoL becomes genuinely internalized and entrenched. Thus, within those cycles there is a different pace of possible changes in the various aspects involved in the development of rule- $\overline{\overline{\overline{2}}}$ v conditions. The three main layers of change, which may well develop at different - even extremely different paces, are rule adoption, rule implementation and rule internalization. The connections between the first two components of the process (RA and RIm) lie in the fact that RA is a condition for RIm and in this way to the development of DRoL when RI is added and considered (see Figure 2.1).

When does rule adoption take place? To disentangle the sub-process that brings about RA we begin with the actions of international actors (IAs), which is part of the anchoring mechanism, to meet the actions of domestic actors, some of whom are change agents. Action of IAs, be they EU officials or representatives, IMF officials, western government representatives, or others, has to be credible. That is, there have to be the commitments and the resources for those actions by the involved actors, otherwise the entire process is bound to fail. A key point in this is what goals are set out by the IAs. If the EU is the actor, then may membership or virtual membership, that is, the involvement in different policies with similar integrative effect, have a similar impact? This is a more specific, but very important question that our research addresses and answers.

\section{Change agents (ChAs)}

Here we borrow this notion from social-constructivist theory, which points to such an additional domestic variable which should be accounted for when seeking to explain rule adoption in the subject states - namely the degree to which change agents are present in the domestic system. According to this notion, change agents or "norm entrepreneurs" (Finnemore and Sikkink 1998) not only mobilize to pressurize decision-makers to adopt democratic rules by increasing the costs for reform-recalcitrant elites, but they also engage domestic decision-makers in processes of persuasion and social 


\section{Leonardo Morlino and Amichai Magen}

learning to redefine their interests and identities. We can distinguish between two main mechanisms by which this process occurs - a structural mechanism and a more agency-centred mechanism.

The first account focuses on institutional isomorphism. Domestic institutions that frequently interact with other institutions (both domestic and external) and private actors (such as private NGOs) are more open to being influenced by change agents and over time converge with the influencing agents in their formal organizational structures, practices, meaning structures and reform patterns (DiMaggio and Powell 1991; Scott and Meyer 1994). The degree of exposure and openness will therefore determine the propensity for social learning and rule adoption. The second, agency-centered mechanism focuses on socialization processes, whereby domestic actors (either governmental or informal) internalize norms and practices in order to become members of international society "in good standing" (Finnemore and Sikkink 1998). They are socialized into appropriateness through processes of persuasion and social learning which redefine their interests, creating momentum for change (Checkel 1999).

In this context, we would take into account the proposition that these processes are facilitated by dense interaction between domestic and external "epistemic communities" - actors with an authoritative claim to knowledge and a normative agenda (Haas 1992) - such as elite decision-makers, bureaucracies, professional associations, NGOs, think-tanks and academics. In practical terms, therefore, the presence or absence of such epistemic communities and the density of their interaction with the external promoter should influence rule adoption and, later on, internalization as well.

\section{Shift in costs and benefits balance (CBB)}

This key notion of costs and benefits of adjustments draws upon a neo-institutional approach that assumes a "logic of consequences" (March and Olsen 1989 . 1988, whereby domestic leaders respond to external democracy promotion according to their calculations of the benefits and costs of compliance. A target state will adopt the rules advanced by an external promoter if and where the benefits of reward exceed the domestic costs of adoption or, if at some point there is an actual shift in the balance between costs and benefits. This general proposition contains several features that need to be unpacked.

First, we need to take account of the degree of 'misfit' or basic differences between the domestic norms, rules and policy willingness, on the one hand, and the norms and rules promoted by the EU, on the other hand. These differences represent "adaptation pressure" (Borzel and Risse 2000). Clearly, some adaptation pressure must exist for change to occur - a perfect fit between the domestic and external rule obviates the need for rule transfer. The greater the misfit, the greater the adaptation pressure will be. Second, according to this notion the size of domestic compliance costs and their distribution among domestic actors will greatly influence the decision 
whether to accept or reject the rule promoted. Thus, the costs will be higher and not acceptable, or lower and acceptable, depending on: (1) the differences between the domestic and external rule; (2) whether the rule advanced by the external promoter relates to a matter of 'low politics' or a matter of 'high politics', that is, at the core of national power arrangements; and (3) the strength of the domestic opposition to its adoption. Adoption costs can have different sources: (1) they may take the form of opportunity costs of foregoing alternative rewards offered by adopting rules other than those promoted by the external actor; (2) they may entail the constraining of autonomous behavior by the target state; (3) they may produce welfare or power costs for public or private actors in the domestic system.

The preferences of the government and other "veto players" - i.e. actors whose agreement is necessary for a change in the status quo - are a critical component here (Tsebelis 2002). We will therefore need to account for the veto players with significant net costs of rule adoption, as well as the relative strength of veto players in different policy contexts. On the basis of the literature related to Europeanization and the central and eastern European countries (Borzel and Risse 2000; Dimitrova 2002; Schimmelfennig, Engert and Knobel 2003), we can hypothesize that rule adoption will be easier and more effective in countries and policy areas where the veto players incurring costs are weaker and can be overcome.

A key aspect is the shift in the CBB in the perception of decision-makers as a result of the interaction between international actors (IAs) and change agents (ChAs). In fact, because of this interaction there may be changes in opportunity structures, empowerment of ChAs or other governmental elite, or civil society groups, and relative weakening of veto players. If some of these partially or largely take place, then there is a shift in the CBB. This shift may bring about a policy reassessment and the actual subsequent rule adoption when there is domestic fluidity, or the opposite situation, that is, domestic stability, but with a diffuse perception of legitimacy of the RA. Moreover, no real alternative is present.

Domestic fluidity posits that external democracy promotion is more likely to be effective in uncertain (or 'fluid') political environments, when state actors will be more open to new solutions and the possibility of substantial domestic change. According to this hypothesis, in situations of political fluidity - such as following the collapse of an ideological regime or in the aftermath of deep internal crisis or conflict - where there are elite and popular pressures for a re-orientation of state direction and state leaders may themselves be new and lack entrenched directions, the domestic system will be more open to international influence.

\section{The presence of alternatives}

If regimes have (or, more accurately, perceive themselves to have) economic and political alternatives, they will be less likely to be influenced by pressures 
from a given international actor. Put differently, we need to ask what is the subject country's "best alternative to inclusion" within the promoting international actor's economic/political system. EU conditionality of any kind, in particular, would not be effective if the target government had other sources offering comparable benefits (Killick 1996, 221-4). Hence, a hypothesis to be tested is that EU influence will be weakened where a neighboring state finds affiliation and support from other powerful international actors Turkey (US), Ukraine (Russia), Morocco (the Arab world), for example. If, on the other hand, the persuader is seen as authoritative - i.e. the EU is viewed as vital to the state's economic and political wellbeing - whereas the influence of other actors is limited, then EU promotion efforts are likely to be more effective.

On the whole, the sub-process of rule adoption is as follows: when credible actions of IAs are complemented by actions of committed change actors, then there are changes in opportunity structures, empowerment of change agents or of governmental elite or of civil society groups and relative weakening of veto players; if so, there is the possibility of a shift in CBB for decision-makers; if there is domestic fluidity and no presence of domestic or international-related alternatives, then the shifts bring a policy reassessment; if there is a policy reassessment, then there can be rule adoption. But there is also the opposite possibility at every step, of course, especially if no policy reassessment occurs. Figure 2.2 summarizes our hypotheses.

When does rule implementation take place? The presence of effective formal institutions provides actors with material, human and ideational resources to undertake rule adoption. We must account, therefore, for situations where domestic actors are willing to adopt and internalize rules promoted by external actors, but where they are unable to undertake the whole or parts of this process by virtue of lacking the necessary action capacity.

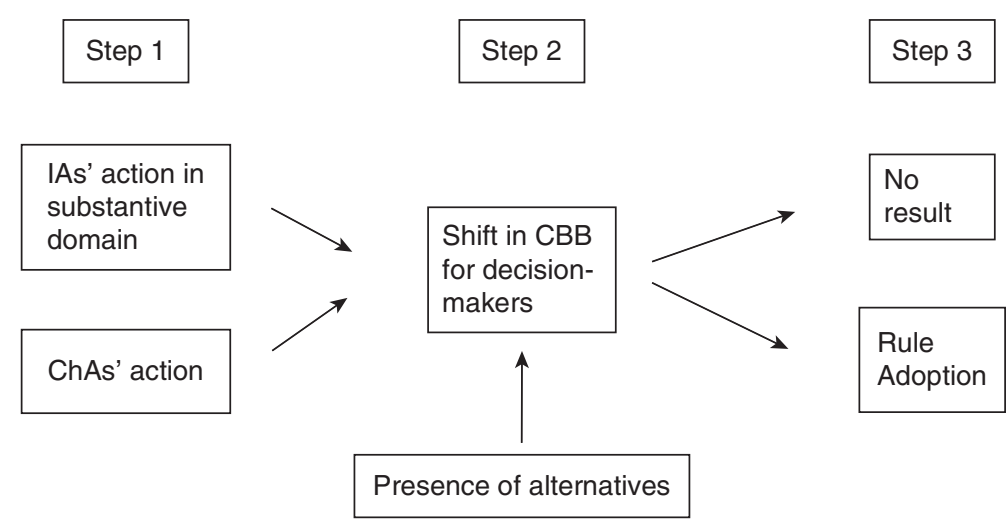

Figure 2.2 The path to rule adoption 
All other factors being equal, the presence of formal facilitating institutions determines whether reform-oriented actors are able to achieve domestic processes of rule implementation.

Again with this second sub-process there is a point of departure when the credible actions of international actors are complemented by the commitment of change agents with regard to: the setting up of an institutional and administrative capacity to formulate, implement and enforce the law; the development of an independent judiciary and a modern justice system; a police reform and civilian control of the security forces. If this happens, then there is a growth in knowledge resources, material resources and learning opportunities inside the country. Such a growth is filtered and occasionally stopped and distorted by bureaucratic inertia and the non-commitment of decision-makers. If this happens to a high degree, then there is no improvement in IAC and even the rule adoption is seriously undermined. If bureaucratic inertia and non-commitment are successfully overcome by the complementary commitments mentioned earlier of international and domestic actors, then an improvement in IAC is achieved and rule implementation is possible. Figure 2.3 summarizes the path of a part of this second sub-process, where special attention should be devoted to step 2 .

When does rule internalization take place? The fabric of each of our subject countries is, to a considerable degree, unique. Differences in legacy, socioeconomic conditions and national culture can be neither ignored nor controlled for with any scientific rigor - but they can, indeed must, be recognized and accounted for as fully as possible. Achieving a deep contextual understanding of domestic conditions is very important. ${ }^{22}$ However, the third sub-process of RI has its own path, which can be applied to each of the case study countries under scrutiny.

The starting point is similar to the previous one, but on the whole the subprocess of RI is actually a distinct one, since it concerns essentially cognitive processes at both elite and mass levels. To be effective, this layer of change

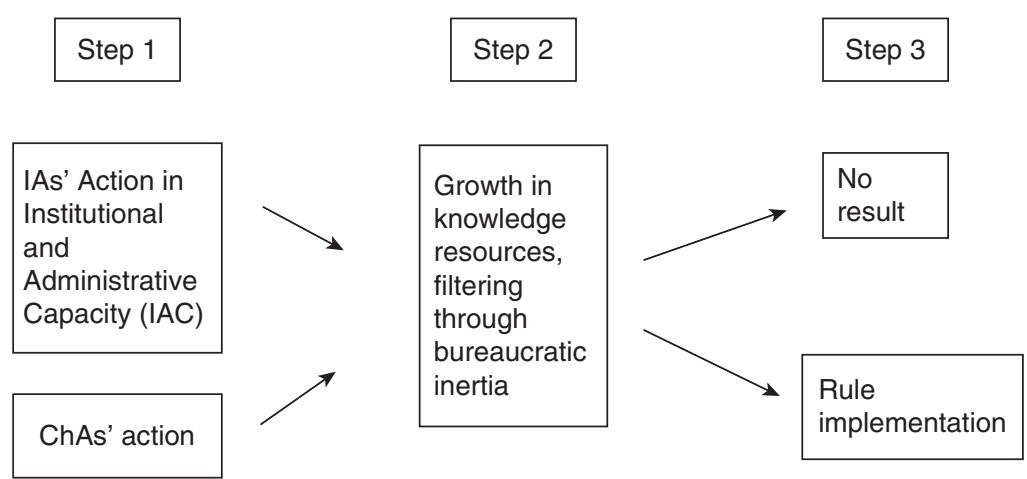

Figure 2.3 The path to rule implementation 


\section{Leonardo Morlino and Amichai Magen}

requires some a priori value commitment of change agents to democracy, better if complemented by the presence of similar values in civil society. This means a commitment to pluralistic liberal values, notably the rule of law, tolerance of opposition, respect for different opinions, civil and political freedoms. If this happens there is the possibility of a diffusion of those values as an effect of rule adoption. Ironically, perhaps, formal rule adoption will take place first, with normative commitment to it coming only later. This is where we can see at work the core of a socialization process that, as happens in other domains when socialization is involved, results in a sort of chain where we find previous existence of rules, protracted implementation of them, absorption and education. If there is no presence of domestic alternatives, then such diffusion is more likely to take place. If there is democratic value diffusion, then the democratic constituency becomes larger and larger, and to different extent rule internalization is a consequent result. If there is an absence, or scant diffusion of democratic values, no diffusion occurs and no enlargement of the democratic constituency, with a consequent lack of rule internalization. The key element, however, is the elapsing of time that brings about that 'habituation phase' Rustow (1970) was recalling or that 'habitualization' process Risse and Sikkink (1999a, 33) developed in the final phase of their spiral model: "whereby international human rights norms are fully institutionalized domestically and norm compliance becomes a habitual practice of actors". In an empirical perspective this usually implies an analysis in the middle run and situations of stronger or weaker socialization. All this will be seen in the empirical chapters and reconsidered in the conclusions. Here, figure 2.4 displays this sub-process and its related hypotheses, and Figure 2.5 the entire model with its different hypothesized connections. The whole model presents an already complex set of connections, steps, dimensions and variable involved. From a strictly theoretical point of view it could have been even more complex, but the purpose was to sketch an empirical model that could be useful in setting the guidelines for sound empirical analysis. This is the challenge we confront in the empirical chapters and in the conclusions.

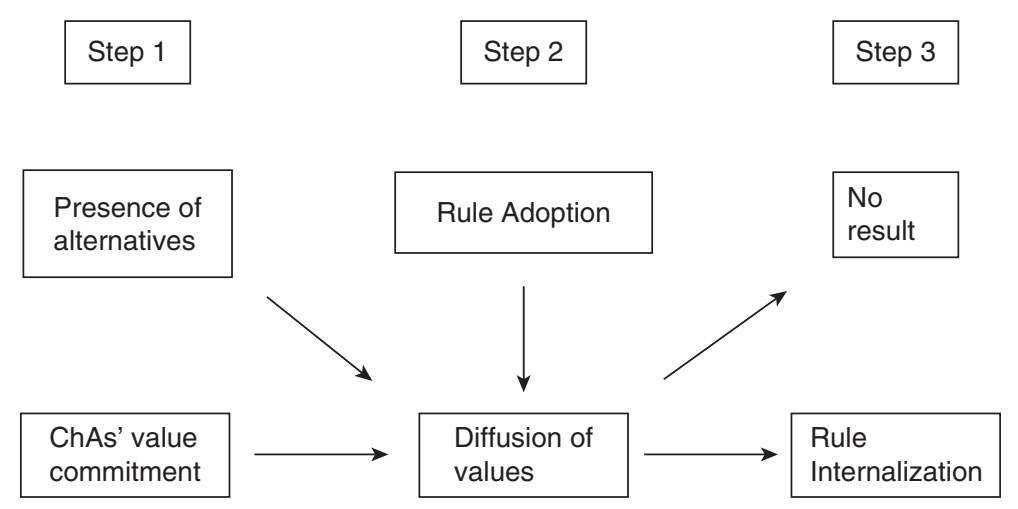

Figure 2.4 The path to rule internalization 


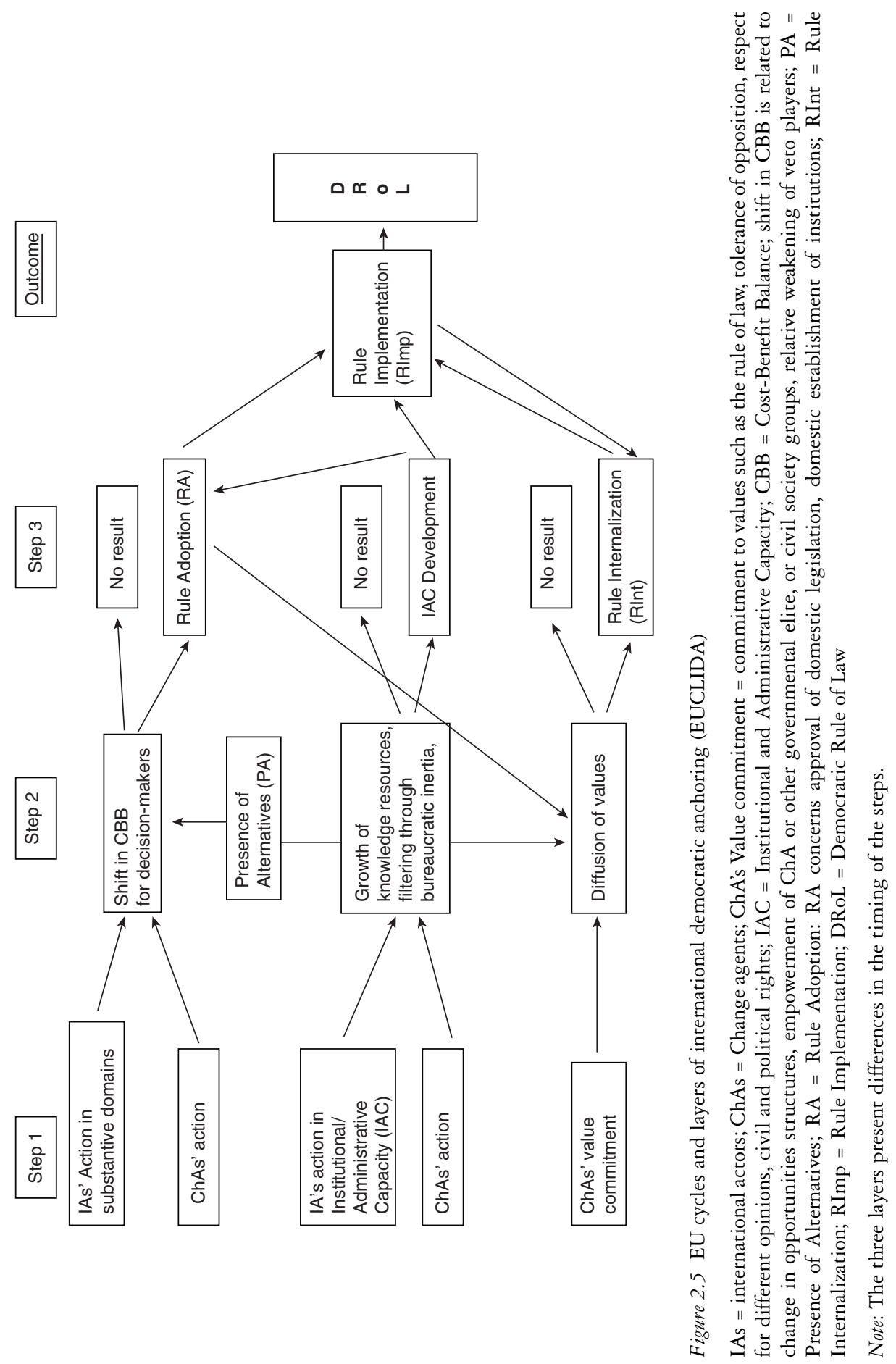




\section{Leonardo Morlino and Amichai Magen}

EUCLIDA does not come out of the blue, but in part develops and integrates components of earlier insights drawn from both interest-based and norm-based theories of compliance. Thus, likewise the 'spiral model' (Risse and Sikkink 1999a) and the conditionality model (Schimmelfennig 2005a), first, the attention is not only on rule adoption, but also rule implementation and internalization, the three layers mentioned above; second, as the other two, it aims to be a dynamics model where different cycles are singled out. But differently from the 'spiral model', EUCLIDA focused on rule of law in its five dimensions and not on human rights alone; had analytic purposes rather than causal ones, that is, it was aimed at developing an integrated analytical framework in the effort of capturing better the reality of different cases; rather than to the impact of principles and ideas on domestic political change, it pays specific attention to the interactions of institutions and people and the shifting of balance that made domestic actors push in the direction of rule of law; consequently, the main focus is on inside-out rather than on outside-in. Differently from other models, such that on conditionality (see above), here another basic mechanism will also be considered, that of socialization, as both conditionality and socialization are indeed the most recurrent ones when the European Union as actor is involved. Finally, differently from any other previous model, EUCLIDA is not a model for every empirical case, but for the cases of hybrid regimes where democratic or quasi-democratic domestic élites are present (see chapter 1). The main consequent asset of this choice should be the possibility of a more precise, in depth analysis as it can be done at a lower level of abstraction when also some of the main notions of the literature of democratization is applied.

\section{Notes}

1 Several earlier studies offer their own typologies as to how international factors may shape processes of democratization. Kubicek $(2003,4-7)$ offers four categories which partly overlap with our own - (1) Control; (2) Contagion; (3) Convergence; and (4) Conditionality. In a typology that similarly tries to conceptualize external influence on domestic change, Schimmelfennig and Sedelmeier (2005a, 10-25) outline three competing explanatory models: (1) the "external incentives model"; (2) the "social learning model"; and (3) the "lesson-drawing model". An earlier, influential conception is Ikenberry and Kupchan's (1990) hegemonic power and socialization thesis. These typologies do not, however, make the distinction between methods of influence and modes interaction, or address the latter in any systematic manner.

2 Military intervention itself ranges from full military occupation to more limited paramilitary intervention, support for one side in an internal conflict, or various types of covert involvement. See Chesterman (2001); Forsythe (1992); Hendrickson (1994); Peceny (1999); Schraeder (1992).

3 See Reisman (1995), supporting military intervention in certain circumstances, versus Roth (2000), arguing against the legality of such interventions.

4 As part of international efforts towards successful implementation of the 1995 Dayton Peace Agreement, an international High Representative has effectively ruled Bosnia-Herzegovina since 1997, with NATO, EU, OSCE and UN involvement. The High Representative's mandate was significantly strengthened at the Peace Implementation Council (PIC) meeting in Bonn in late 1997. Since 2002 the High Representative has "double-hatted" as the EU's Special Representative (EUSR), reflecting a shift in strategy in which the EU has assumed 
greater responsibility to managing the trusteeship and intending to steer Bosnia-Herzegovina into eventual EU membership. See Recchia (2007).

5 The general thrust of the literature is that sanctions are rarely effective in promoting domestic reforms. See: von Hippel (2000); A. Smith (1995); Hufbauer et al. (1990). In contrast, several recent studies assert that the effectiveness of sanctions has been underestimated, partly because of a problem of selection bias, since the bulk of successful coercion episodes end with sanctions threatened but not actually imposed. See, in particular, Drezner (2003); Blake and Klemm (2006). On choices in the design of sanctions regimes, particularly the use of "smart sanctions" see Shagabutdinova and Berejikian (2007). As Marinov (2004, 2) observes: "Since 1977, the use of economic pressure to further liberalization has increased dramatically. Between 1985 and 2000, the number of countries subject to such pressure increased fourfold ... the United States and European Union (EU) member states in particular, have been especially prominent in this rising trend. More than $85 \%$ of all sanctions for democracy have been levied with the participation of either Europe or the U.S”.

6 While all regions (with the exception of the Middle East) have experienced a marked rise in the risk that autocracy will be sanctioned, substantial regional variation in the likelihood of sanctioning exists. A Latin American country which experienced a lapse in democracy in 2000, Marinov writes, had a greater than $80 \%$ risk of being sanctioned by outsiders.

7 As Judith Kelley (2004b, 425-6) observes, the body of theoretical and empirical research on the use of democratic conditionality by international actors (as opposed to the structural adjustment conditionality policies of the IFIs) is sparse and until recently the strategy had not been subjected to close analysis. See also Svensson (2000), showing that the voluminous literature on foreign aid and development has generally not dealt with incentive problems in the donor-recipient relationship, and credibility and institutional design issues in foreign aid policy, in particular.

8 The notion of "reinforcement by reward" is articulated by Schimmelfennig, Engert and Knobel (2003, 496).

9 For the Millennium Challenge Corporation (MCC) selection criteria see: http:// www.mcc.gov/selection/index.php. For commentary on the MCC see the series of papers published by the Center for Global Development: http://www.cgdev.org/nv/ features_MCA.html. On the MCC see also: Soederberg (2004); Radelet (2003).

10 For an excellent summary of the literature on external incentives see: Schimmelfennig and Sedelmeier (2005a). International lawyers have approached similar questions, but from the point of view of compliance with international rules and norms. See, in particular, Hathaway (2002); (2005).

11 Including corruption control, prominent court systems, civil service professionalization, modern administrative practices, as well as environmental, educational and scientific policies. See, in particular, Meyer et al. (1997a); Ramirez, Drori, Meyer and Schøfer (2003).

12 See Schraeder (2003). The international community's swift and decisive verbal condemnation of General Oviedo's attempted military coup in Paraguay in April 1996, for instance, played a pivotal role in castigating the military's insubordination against civilian control as normatively unacceptable, and bolstered the weak elected government, effectively saving the country's fragile democracy from collapse. On this case see Valenzuela (1997).

13 These include: The Committee of Legal Affairs and Human Rights (CLAHR); The European Committee on Legal Cooperation (CDCJ); The European Committee on Crime Problems (CDPC); The Group of States Against Corruption (GRECO); The Committee of Experts on Terrorism (CODEXTER), and the European Commission on Democracy Through Law (Venice Commission). Many of these activities are coordinated by the Directorate General of Legal Affairs of the Parliamentary Assembly of the Council of Europe (see: http://www.coe.int/t/dg1/default_en.asp).-

14 For a summary of existing indicators and the reasons for their rapid emergence in the last decade see: The World Bank: A Decade of Measuring the Quality of Governance: governance matters 2006 (2006) (available at: http://siteresources.worldbank.org/ INTWBIGOVANTCOR/Resources/1740479-1150402582357/266182 911580); Arndt and Oman (2006); Munck and Verkuilen (2002). 


\section{Leonardo Morlino and Amichai Magen}

15 The privately-owned International Crisis Risk Guide (ICRG), for example, provides a political risk assessment of 161 countries comprising, inter alia, contract viability and risk of property expropriation, corruption, civilian control of the military, bureaucratic quality, as well as strength and impartiality of the legal system. The ICRG is compiled by the PRS Group (see: http://www.prsgroup.com/). Similarly, from the non-profit, NGO sector, Transparency International (TI) and Freedom House (FH) produce the widely cited Corruption Perceptions Index (CPI) and Freedom in the World index, respectively; ranking the vast majority of countries in the world on comparative scales, covering, inter alia, rule- $\bar{\equiv}$ dimensions. Freedom House's measure of the degree to which "civil liberties" are protected in 192 countries, for instance, includes four specific questions under the title "the rule of law" - asking whether there is an independent judiciary, whether the rule of law prevails in civil and criminal proceedings, if the police operates under civilian control, and if individuals are protected from police terror, unjustified imprisonment, torture or exile. Among international institutions, the World Bank produce major sets of influential governance indicators, partly dedicated to assessment of rule- $\mathrm{\equiv}$ conditions in the monitored countries. The Country Policy Institutions Assessments (CPIAs) - published by the Bank annually since 1977 but only publicly disclosed from 2006 - cover 16 criteria, including business regulatory environment, property rights, rules-based governance, quality of budgetary and financial management, quality of public administration, and transparency-accountability-corruption in the public sector. More importantly still, since 1996 the World Bank Institute has produced the Worldwide Governance Indicators (or "KKZ" indicators), which have become the most widely quoted governance indicators by the media, academia, and the broader donor community. For a critique of the way in which governance indicators are compiled and used see Arndt and Oman (2006).

16 The EU has not been the sole example of this phenomenon. In a series of large-scale, ongoing processes, the main international organizations of the transatlantic community - the EU, NATO, the Council of Europe and the OSCE - have actively sought to transmit their rules, institutions and norms, by combining membership conditionality and financial assistance with engagement in a long-term, multilevel set of deliberative processes of varying content and density. Through the establishment of permanent links (such as the Partnership for Peace, PFP, policy), joint training operations and monitoring, NATO, for instance, has played an increasingly structured role in socializing military leaders in Central and Eastern Europe to the idea of civilian control of the military, transparent security budgets and other modern regulatory standards. Foregoing the EU's rigorous architecture of membership conditionality, similarly, the Council of Europe and the OSCE have opted primarily for a post-accession model of influence through socialization.

17 OAS General Assembly, Resolution 1062

18 For the text of the Inter-American Democratic Charter see: http://www.oas.org/ OASpage/eng/ Documents/ Democractic_Charter.htm. See the annual reports of the InterAmerican Juridical Committee (available at: http://www.oas.org/cji/eng/ reports_iajc.htm).

19 Preamble to the Constitutive Act of the African Union (2000) (text available at: http://www.au2002.gov.za/docs/key_oau/au_act.htm). Article $4(\mathrm{~m})$ of the Constitutive Act also states that the African Union shall act in accordance with the principle of: "Respect for democratic principles, human rights, the rule of law and good governance".

20 Checkel $(2005,804)$ calls these two types of socialization "Type I" and "Type II", respectively.

21 On this mechanism Schimmelfennig and Scholtz (2007) developed a very effective empirical analysis on 36 cases to show its salience.

22 To reach such an understanding a detailed "country report" has been prepared on each country. The template of the report is standard, covering: key facts and figures; historical and political background with detailed post-Cold War coverage; an analysis of governmental structure and practice (executive, legislative and judiciary); an analysis of democratic conditions (electoral processes, economic conditions, civil society, legacy and conflict issues, protection of freedoms); as well as international factors (membership in variety of international and regional organizations and fora, subscription to international treaties and relationship with other major promoters, where applicable). 